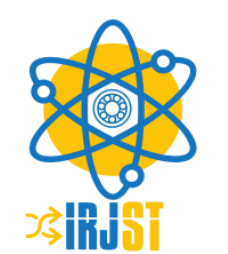

Available online at https://www.irjst.com/

International Research Journal of Science and Technology

ISSN: 2707-3955

DOI: https://doi.org/10.46378/irjst.2021.020303

\title{
Employability of Information Technology Education Graduates of President Ramon Magsaysay State University, Castillejos, Zambales from 2015-2020.
}

\author{
Michael G. Albino ${ }^{*}$, Femia S. Albino \\ 1,2 President Ramon Magsaysay State University, Castillejos, Zambales, Philippines, 2208
}

\begin{tabular}{lll}
\multicolumn{2}{l}{ Paper Status } & \\
Received & May 2021 \\
Accepted & $:$ & Jun 2021 \\
Published & $:$ & Jun 2021
\end{tabular}

Key Words

BSCS graduates

Employability

IT Education Graduates

\begin{abstract}
This study determined the employment status of IT Education Graduates of PRMSU Castillejos Zambales from 2015-2020 specifically the BS Computer Science Graduates. The study also assessed the relevance of the present job of the graduaterespondents and the reasons of their unemployment. The finding of the research study will serve as basis for further study that will determine the problems encountered by the graduates in finding job, faculty performance and update or enhance the BSCS curricula to meet the demand of the industry in response to Industrial Revolution 4.0 mandate. The researchers administered a survey to the respondents to gather necessary data on their employment and job placement. There were 60 percent of the graduaterespondents who were presently employed as rank and file or clerical level; majority have professional, technical and supervisory position job which is relevant to the graduate outcomes. The survey revealed that 60 percent of the respondents' reason for unemployment was family concern and decided not to find a job. Based on the data gathered from the respondents, the BSCS graduates were employed majority related to their course and the necessary theoretical and technical skills they gained in school helped them to find job. It is strongly recommended that further study should be done in the future to further enhance the study.
\end{abstract}

Copyright @ 2021: Michael G. Albino, Femia S. Albino. This is an open-access distribution, and reproduction in any medium provided Access article distributed under the Creative Commons Attribution License the original work is properly cited License, which permits unrestricted use.

Citation: Michael G. Albino, Femia S. Albino.. "Employability of Information Technology Education Graduates of President Ramon Magsaysay State University, Castillejos, Zambales from 2015-2020. ”, 2 (3), 440-443, 2021.

\section{Introduction}

The recently released result of the United Nations Conference on Trade and Development's (UNCTAD) Technology and Innovation 2021 showed that Philippines ranked second overperformer in ICT development, and some other fields. The result shows that Philippines as a developing country in Asia exceeded with a high ranking for industry in hightechnology manufacturing, particularly electronics [1]. With this achievement, Philippines is continuously improving its degree programs under the Commission

\footnotetext{
* Corresponding Author: Michael G. Albino

President Ramon Magsaysay State University, Castillejos,

Zambales, Philippines, 2208

Email: malbino0203@gmail.com
}

on Higher Education (CHED) in strengthening its capability for offering Information Technology Education (ITE) programs across the country.

"One of the researchers' recommendations for improving the marketability of BSIT and BSCS programs, and thus the employability of the graduates they produce," the authors conclude, "is a periodic examination of the syllabus by educational leaders, alumni, and business representatives to ensure that graduates are prepared with the defined data and skills provided within the business" [2].

It is important that graduates of the 21 st-century education, the necessary skill such as employability skill is required aside from technical knowledge in able for the applicant to succeed in finding job [3]. 
Higher Education institutions must ensure that graduates of their schools must obtained necessary knowledge and skills to meet the standards for employers set for their workplace [4]. One factor that schools must address towards combating unemployment of ITE graduates was English proficiency among the graduates. It is recommended that strengthening the English proficiency program of the ITE graduates must be addressed for them to become globally competitive graduates and to seek employment in the future [5].

According to the report of the Philippine Statistics Authority in March 9, 2021 highlighted that on the 2021 Labor Force Survey (LFS), unemployment rate in seven [6] areas of the country. In January 2021, the country's unemployment rate was stated to be higher compared to the national estimate of $8.7 \%$.

A greater percentage from the respondents was work along their field of specialization. The majority of respondents work on a permanent basis and are gainfully employed, according to their job status and nature of employment [7]. The researchers aimed to determine the employment status of Bachelor of Science in Computer Science (BSCS) of President Ramon Magsaysay State University, Castillejos, Zambales from 2015-2020. It aims to assess employability rate of the graduates and the alignment of their current job/occupation to the graduates' outcome based on CHED Memorandum Order No. 25 s. 2015 issued by CHED for further improvement of the curriculum.

\section{Materials and Methods}

\subsection{Research Design}

The researchers utilized descriptive research design for the conduct of the research study. It allows the researchers to collect necessary data from the respondents on the different questions incorporated in the survey questionnaire relative to their employment status and its alignment to the graduate outcomes of the subject under study.

Along with this, the objective of a descriptive research study was to describe individuals, occurrences, or conditions can be defined by observing them in their natural state [8]. A descriptive study design is also a viable tool for studying particular subjects and as a prelude to more rigorous research [6].

\subsection{Respondents and Sampling Technique}

The researchers used non probability sampling for identifying the respondents of this study. For the selection of respondents, the researchers selected the target respondents of the study based on their availability. Convenience sampling techniques was used by the researchers. A total of 97 BS Computer
Science graduates from year 2015-2020 was the target participants of the study.

Table 1. Graduate-Respondents According to Year Graduated

\begin{tabular}{lll}
\hline Year Graduated & Frequency & Percentage $(\%)$ \\
\hline 2015 & 13 & 13.40 \\
2016 & 19 & 19.59 \\
2017 & 18 & 18.56 \\
2018 & 14 & 14.43 \\
2019 & 32 & 32.99 \\
2020 & 1 & 1.03 \\
\hline Total & 97 & 100.00 \\
\hline
\end{tabular}

Table 1. shows the distribution of respondents based on the year they graduated. It is noticeable that year 2019 has the biggest number of graduates with 32.99 percent followed by year 2016 with 19.59 percent, year 2017 with 18.56 percent, year 2015 with 13.40 percent and year 2020 with 1.03 percent.

\subsection{Research Instrument}

The researchers administered the survey questionnaire to the respondents through social media application platforms (Facebook messenger, Email, etc.) due to the limited face-to-face interaction brought by the pandemic. The researchers assured the respondents of the data privacy and confidentiality of the data they provided for the study.

\subsection{Data Collection}

The researchers administered the survey questionnaire to the respondents through social media application platforms (Facebook messenger, Email, etc.) due to the limited face-to-face interaction brought by the pandemic. The researchers assured the respondents of the data privacy and confidentiality of the data they provided for the study.

\subsection{Data Analysis}

For data analysis, the information gathered from the respondents was categorized, tabulated, and coded. The data obtained from the administration of the survey questionnaire was interpreted using the statistical tools mentioned below.

(1) Percentage. It was used to determine the percentage of the graduate-respondents profile based on the given criteria.

(2) Ranking. It was used to identify the priority of the gathered data based on each criterion.

\section{Results and Discussion}

The results of the data gathered through the survey questionnaire administered by the researchers using commonly accepted statistical methods and principles are discussed in the table and figures below. This study aimed to determine the status of employment of BSCS graduates at President Ramon Magsaysay State 
University, Castillejos, Zambales from year 20152020.

Figure 1 shows that $57 \%$ of the graduate-respondents was male and $43 \%$ was female. It can be noted that more graduates were male compared to female.

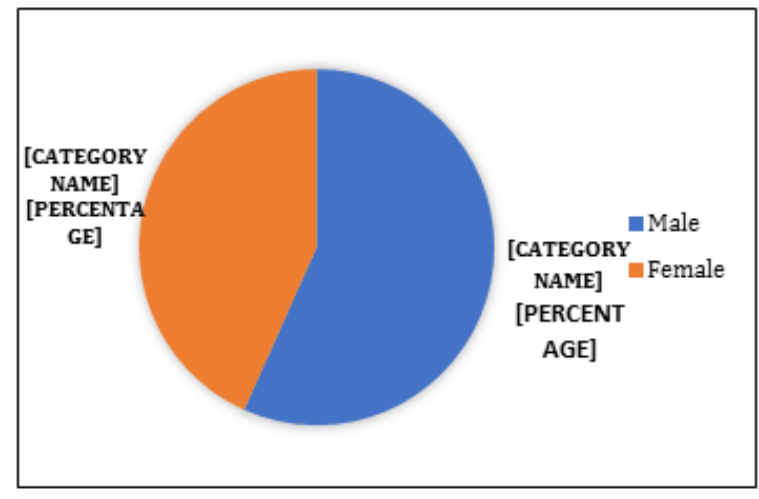

Figure 1. Profile of Graduates by Gender

As shown in table 2, 86.60\% of the respondents landed on a job related to their completed course while $13.40 \%$ of the employed respondents landed on a job not related to their course completed. It can be noticed that a high percentage of graduates have a job related to their field of expertise.

Table 2: Employment Profile of the BSCS graduates

\begin{tabular}{lll}
\hline Employment Profile & Frequency & $\%$ \\
\hline $\begin{array}{l}\text { Related to the course } \\
\text { completed }\end{array}$ & 84 & 86.60 \\
$\begin{array}{l}\text { Not related to the course } \\
\text { completed }\end{array}$ & 13 & 13.40 \\
\hline
\end{tabular}

It is noticeable that graduate-respondents were employed in a job which they can practice the knowledge and skills earned from the course completed. It can also be noted that more graduates earned necessary skills both theoretical and technical skills that helped them in finding job related to their field of expertise.

Table 3: Employment Status of BSCS graduates

\begin{tabular}{llll}
\hline Job & Frequency & $\%$ & Rank \\
\hline $\begin{array}{l}\text { Rank and File or } \\
\text { Clerical }\end{array}$ & 60 & 61.86 & 1 \\
$\begin{array}{l}\text { Professional, } \\
\text { Technical and }\end{array}$ & 22 & 22.68 & 2 \\
$\begin{array}{l}\text { Supervisory } \\
\text { Managerial or }\end{array}$ & 2 & & \\
Executive & 8 & 2.06 & 5 \\
Self-Employed & 82 & 8.25 & 3 \\
Total & 92 & 94.85 & \\
Unemployed & 5 & 5.15 & 4 \\
Grand Total & 97 & 100.00 & \\
\hline
\end{tabular}

In terms of present employment, it is noticeable that $61.86 \%$ of the gradates was having their job in rank and file or clerical level. It was followed by $22.86 \%$ of the respondents in professional, technical and supervisory job, $8.25 \%$ respondents were selfemployed, $2.06 \%$ of the respondents were employed in managerial or executive level and $5.15 \%$ were unemployed.

Table 4: Unemployment Reason of GraduateRespondents

\begin{tabular}{|c|c|c|c|}
\hline $\begin{array}{l}\text { Unemployment } \\
\text { Reasons }\end{array}$ & Frequency & $\%$ & Rank \\
\hline $\begin{array}{l}\text { Advance or further } \\
\text { study }\end{array}$ & 0 & 0 & \\
\hline $\begin{array}{l}\text { Family Concern and } \\
\text { decided not to find a } \\
\text { job }\end{array}$ & 3 & 60 & 1 \\
\hline $\begin{array}{l}\text { Health related } \\
\text { reason(s) }\end{array}$ & 0 & 0 & \\
\hline $\begin{array}{l}\text { Lack of work } \\
\text { experience }\end{array}$ & 0 & 0 & \\
\hline No job opportunity & 0 & 0 & \\
\hline $\begin{array}{l}\text { Did not look for a } \\
\text { job }\end{array}$ & 1 & 20 & 2 \\
\hline Deceased & 1 & 20 & 2 \\
\hline
\end{tabular}

Table 4 shows the frequency distribution of respondents according to reasons of unemployment. The table shows that $3(60 \%)$ of the responses were family concern and decided not to find a job was the number 1 reason of their unemployment followed by did not look for a job with 1 (20\%) and 1 (20\%) was deceased.

\section{Conclusion}

The researchers concluded the following based on the collected data from the graduate-respondents: Majority of the graduate-respondents were male, meaning most male was interested in studying computer science compared to female.

Among the respondent's employment data, majority of the graduate-respondents were landed to a job which was related to their course completed and acquired necessary theoretical and technical skill that helped them in their respective job. The employability of the graduates shows relatedness of the subjects taught by their instructors that helped them in their job. One of the main reasons of their unemployment was family problem and not finding for a job after graduation.

In line with the aforementioned conclusions, the researchers recommended a further study to identify the problems encountered by the graduates in finding job, faculty performance and curriculum and instruction. 


\section{References}

[1]. United Nations Conference on Trade and Development (2021). Technology and Innovation $\quad 2021$. https://unctad.org/page/technology-andinnovation-report-2021.

[2]. Albina, Albert \& Sumagaysay, Lilian. (2020). Employability tracer study of Information Technology Education graduates from a state university in the Philippines. Social Sciences \& Humanities Open, $\quad 1-6 . \quad 2 . \quad 100055$. 10.1016/j.ssaho.2020.100055.

[3]. Suarta, I Made \& Suwintana, I Ketut \& Pranadi, Fajar \& Hariyanti, Ni Kadek. (2017). Employability Skills Required by the 21st Century Workplace: A Literature Review of Labor Market Demand. 10.2991/ictvt-17.2017.58.

[4]. Pirani, J.A. (2004). Information Technology Alignment in Higher Education. Educause Center for Applied Research.

[5]. Balingbing, A.B (2014). Tracer Study of BS in Information Technology (BSIT) Graduates of Camarines Sur Polytechnic Colleges, Nabua, Camarines Sur from 2004 to 2010. Asia Pacific Journal of Multidisciplinary Research.

[6]. Shuttleworth, M. (2021). Descriptive Research Design. https://explorable.com/descriptiveresearch-design.

[7]. Macatangay, L. (2013). Tracer Study of BSCS Graduates of Lyceum of the Philippines University from 2004-2009. Social Science and Humanities. Academic Research International Journal.https://www.journals.savap.org.pk.

[8]. Siedlecki, Sandra. (2020). Understanding Descriptive Research Designs and Methods. Clinical nurse specialist CNS. 34. 8-12. 10.1097/NUR.0000000000000493. 